OPTIMUM. STUDIA EKONOMICZNE NR 1 (61) 2013

István TAKÁCS ${ }^{1}$

\title{
PERFORMANCE MEASUREMENT OF HUMAN RESOURCE IN HUNGARIAN HIGHER EDUCATION
}

\begin{abstract}
Summary
Measuring and evaluating performance, and - even more - exploring the factors influencing performance is of key importance both in the case of business enterprises and non-profit- oriented public organizations. Well-known economists and businessmen try to improve the measuring methods. Measuring the fulfilment of requirements regarding public organizations is typically made by analysing the financial management, but obviously it is not enough. The objective of the public sector is to create public goods which have no obvious and marketable value. Measuring the performance of man who plays a key role in value creation is important because - in addition to increasing the efficiency of the organization - he also has an important role in motivation. The paper reviews the performance measurement of staff working in the public sector organizations and, based on a survey by a Hungarian university, evaluate the attitudes of the public sector staff concerning performance evaluation.
\end{abstract}

Keywords: higher education, comparative analysis, public goods, efficiency, survey

\section{Introduction}

(...) when you can measure what you are speaking about, and express it in numbers, you know something about it; but when you cannot measure it, when you cannot express it in numbers, your knowledge is of a meagre and unsatisfactory kind; it may be the beginning of knowledge, but you have scarcely in your thoughts advanced to the stage of science, whatever the matter may be.

[Kelvin 1889 pp. 80-81]

The topic of the article is closely connected to human resources management. The authors, however, do not intend to describe it from the classical HR management approaches but focus their attention on the dilemmas of HR management when they try to assess the performance of the labour force. We have been inspired from several sources in our work, for example from the legislative side. The assessment of employees in the public sector (civil servants, public officials) should have been made regularly (generally every three years), but the former system contained a lot of formal elements and the subjective attitude of managers had a great share in the procedure. In the 2000s, the legislation argued for the performance measuring of employees of the public sector by the force of law. On the other hand, a lot of questions arose in connection with the

${ }^{1}$ Dr. hab. Takács, István, Károly Róbert College, Gyöngyös, Hungary, e-mail: itakacs@karolyrobert.hu. 
implementation of the procedure, and as a part of this - although not as competent experts but those who can track the progress in the process - we collected experience and tried to perform a survey in which we examined the knowledge and opinion of civil servants about the performance evaluation that they were subjected to. In the examination, we focused on the measurability problems of staff's performance in public sector organizations and less on the role of the performance measured in human resource management and the motivation of employees.

First, we have to discuss the problems of performance measurement. The concept of performance management was explained by a lot of authors. Hereby only a few are mentioned who are more closely related in a sense to the later topics of our article. The approaches, of course, mostly reflect the values of the business sector and evaluate on the basis of directly measurable performances and income.

According to Neely et al. [Neely et al.1995] the performance measurement is a topic often discussed but rarely defined. They proposed definitions of performance measurement, a performance measure and a performance measurement system as follows:

- "Performance measurement can be defined as the process of quantifying the efficiency and effectiveness of action."

- "A performance measure can be defined as a metric used to quantify the efficiency and/or effectiveness of action."

- "A performance measurement system can be defined as the set of metrics used to quantify both the efficiency and effectiveness of actions" [See also: Bourne et al. 2003 p. 3].

In the case of non-profit activities, however, quite a few questions should be faced when evaluating effectiveness and efficiency. In the course of non-profit activities, public goods are produced the value of which and the method of evaluation itself implies a set of uncertainties. The economics of externalities tries to provide tools for those dealing with evaluation but the transformation of theoretical models into actual values is always followed by debates.

During measurement we also have to consider what kind of information is given by the composed indices to the competent users: to the person who is measured, who can position himself in the organization on the basis of this in order to realize his own career plan - if he is conscious enough. The executive head also receives information about the contribution of the employee to the fulfilment of the mission of the organization as well as reference values for the application of motivation tools.

With a certain abstraction, the following criteria system regarding business entities properly describes the general requirements towards the measuring system that can be used in non-profit-orientated public sector organizations:

- CComprehensive: The measurement system captures all relevant constituencies and stakeholders for the process.

- Causally oriented: The measurement system tracks those activities and indicators that influence future, as well as current performance.

- Vertically integrated: The measurement system translates the overall firm strategy to all decision makers within the organization and is connected to the proper reward system. 
- Horizontally integrated: The measurement system includes all pertinent activities, functions, and departments along the process.

- Internally comparable: The measurement system recognizes and allows for trade-offs between the different dimensions of performance.

- Useful: The measurement system is ready understandable by the decisionmakers and provides a guide for action to be taken" [Caplice, Sheffi 1995 p. 63].

The main objectives of performance measurement systems are as follows: control, reporting, planning and making business decisions [Wimmer et al. 2010]. If we examine the above criteria from this aspect, it becomes obvious that their fulfilment depends on the quality and information content of applied measuring tools and indices. Meadows (1998) drafted some useful guide in this regard. (It should be noted, that - in contrary to the above cited requirements about measuring performance as a whole or its partial procedures - Meadows put down these requirements in connection with sustainability, which is very close to the treatment of our examination's target. The requirements are as follows:

- "Clear in value: no uncertainty about which direction is good and which is bad.

- Clear in content: easily understandable, with units that make sense, expressed in imaginable, not eye-glazing, numbers.

- Compelling: interesting, exciting, suggestive or effective action.

- Policy relevant: for all stakeholders in the system, including the least powerful.

- Feasible: measurable at reasonable cost.

- Sufficient: not too much information to comprehend, not too little to give an adequate picture of the situation.

- Timely: compliable without long delays.

- Appropriate in scale: not over- or under-aggregated.

- Democratic: people should have input to indicator choice and have access to results.

- Supplementary: should include what people can't measure for themselves ...

- Participatory: should make use of what people can measure for themselves...

- Hierarchical: so a user can delve down to details if desired but can also get the general message quickly.

- Pbysical: money and prices are noisy, inflatable, slippery, and unstably exchangeable...

- Leading: so they can provide information in time to act on it.

- Tentative: up for discussion, learning, and change" [Meadows 1998 pp. 1718].

Then again, it is the problem of measuring, that - although all the employed indices meet the above requirements, they come from past data, often from different lengths of time, the evaluation of which in a certain context gives disputed results and makes the 
predictability and assessment of future performance problematic. The other problem is that they decrease the information value of aggregates created from individual indices.

As regards higher education targeted by the present study, one of the key evaluation factors in the national and international measurement of institutional performance [Breakwell, Tytherleigh 2010] is people, the key factor of servicing. The different degree of human resources and strategic orientation of non-profit organizations (NPOs) results in different types of human resource management activities, which in turn determine the performance of employees and consequently the organization (Figure 1) [Ridder et al. 2011].

It is obvious that if both the HR and the strategic orientation is of a low level, we can speak only about administrative human resource management and in order to implement value-based human resources management, both the HR and strategic orientation should be at a high level. Since the human capital in higher education is concentrated and extremely high, this latter approach should be enforced in the institutions. [Akingbola 2012] Whether it is realized or not, it depends on the commitment of management.

The attention given to this area depends partly on the personal qualities of executives and, consequently, their leadership style which is determined by their qualities. The management style determines the organizational culture. According to the $\mathrm{X}$ and $\mathrm{Y}$ theoretical model by McGregor the oppressive (autocrat) and liberal management introduces different organizational structure within the firm, which decisively affects the development and performance of the organization. The autocratic and oppressive management (Theory $\mathrm{X}$ ) keeps the organization under rigorous control, but there is no development, thus the organizational activities and performance are limited and a depressed organizational culture is formed. Liberal leadership (Theory $\mathrm{Y}$ ) is developmentoriented, the control is made through achievement, continuous improvement, authorization and transferring responsibility. The management works as a supporter of the organization, it is not restricting but enhances self-realization of staff thus increasing the performance of the organization. Empirical research also confirms the theoretical model, that is the organizational culture has a considerable impact on the performance of organization [Zhang et al. 2008].

The performance and competencies of human resource (employee) are closely connected to each other. The performance can be increased by developing the latter [Marrewijk, Timmers 2003]. It obviously means that measuring the competencies is an important evaluation criterion within performance measurement if the management aims to improve the performance of the staff and - through this - the performance of organization. 
FIGURE 1.

\section{Typology of HR architectures and their effects in NPOs}

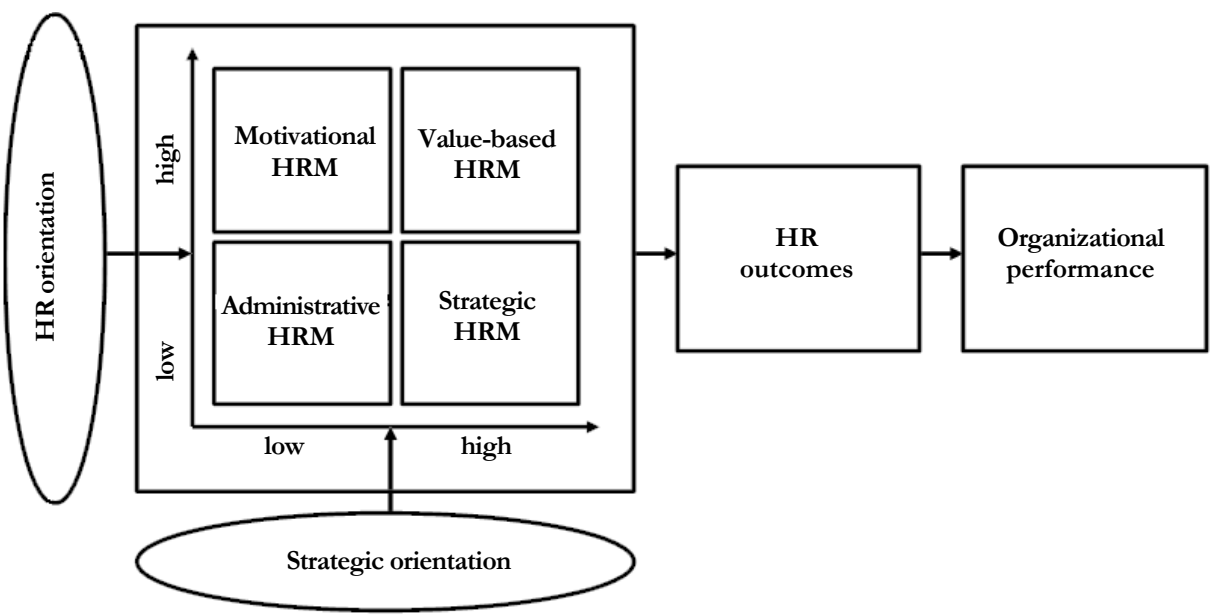

Resource: [Ridder et al. 2011 p. 10].

The development of competencies is connected with the employee performance management and personal development. One of its well-known criteria system, as Key Performance Indicators (KPIs), is the system of SMART indicators (Specific, Measurable, Attainable, Relevant, Timely) [Doran 1981], complemented with feedback (Evaluate, Re-evaluate) functions. Typical SMART questions can be like the following[Meyer 2003] -Specific: What: What do I want to accomplish?; Why: Specific reasons, purpose or benefits of accomplishing the goal.; Who: Who is involved?; Where: Identify a location.; Which: Identify requirements and constraints.; Measurable: How much?; How many?; How will I know when it is accomplished?; Attainable: How: How can the goal be accomplished?; Relevant: Does this seem worthwhile?; Is this the right time?; Does this match our other efforts/needs?; Are you the right person?; Timely: When?; What can I do in six months from now?; What can I do today? The questions can also give reasons for the performance measurement of human resource, adequately to the objectives of the organization.

As regards higher education, the issue is in a special context due to the teachers' autonomy. How can a teacher be evaluated if - in theory - he/she can autonomously determine many key parameters of his/her own activities. At the same time, however, the experiences collected through the implementation of quality assurance systems prove that the autonomy of teachers and the operation of a regulated system can be harmonized, without harming the former one. [Hoecht 2006] It can be concluded that the implementation of systems measuring the key performance indicators can be compatible with teaching autonomy of teachers and referring to the autonomy actually means the intent to avoid control. Referring back, however, to the Theory Y model of 
McGregor, the control is also part of the liberal management style and related organization culture, but the implementation of control extends the fields of responsibility (even to the person in some elements).

The evaluation systems of human resource performance should consider the fact that in the long run the employee (even if he is a professor) will measure the efforts (inputs added by him) and the yields and profits resulted by his work (See Adams' Equity Theory: [Adams 1965]). The permanent imbalance (workplace or management which does not recognize achievements) will make unmotivated, decreases performance to a level which is considered proportional to inputs. If the measurement system of employee performance is not able to measure whether the performance of the employee and the outputs of work are in proportion to each other, then it is unsuitable for the efficient support of human resources management and for the implementation of organizational goals of the management.

We have to outline shortly the special feature of state higher education institutions, that is they work as part of the state budget. The condition system of the operation of institutions is determined by the actual role concept of the state and, as a consequence, the extension of its responsibility and the budget that can be spent - the performance of the economy [Báger et al. 2009]. Thus the government feels authorized to issue regulations concerning the performance measurement of institutions and their employees [Breakwell, Tytherleigh 2010], to implement evaluating mechanisms (accreditation system, appointment procedure of professors) which try to look objective, but the impact of interests and relation systems (as subjective factors) overwriting measurable requirements can be traced many times.

Public and higher education has a special place within the state budget system. In connection with their evaluation, all the concepts of efficiency, productivity and fairness have significance [Lannert 2004]. Efficiency, however, is often identified only with the use of costs and it is regarded the synonym of "cheapness". Thus efficiency and productivity is often separated for those participating in education (teachers, pedagogues and leaders of institutions) because successful training is not cheap. The intellectual investment utilized for the achievements in professional work is pricey, thus - from this point of view - efficiency and success can be contradictory concepts [Lannert 2004].

Efficiency in its common sense is the ability to achieve the planned impact. In technical sense, that institution can be regarded efficient among the participants of education, the pupils/students of which produce good results in public education according to the basic skill measurements and - concerning higher education - according to the assessment of labour market. As regards the latter, however, the labour market often evaluates not only the applicant, measuring his/her actual knowledge, but also the goodwill or ill will represented by the reputation of the institution. Due to this, the fresh graduates on the labour market often fail at the first screening, independently from their actual performance. In turn, it would affect the judgement of work (performance) in the institution, apart from the fact, that objective measures indicate different (significantly better) performance.

Among the theoretical models examining the non-profit sector, the efficiency models presume efficiency deficit on behalf of non-profit sector. Their basic assumption is 
that the efficiency of activities within these organizations is by all means lower than forprofit organizations because there are no profit-oriented owners [Bartal 2005]. A lot of articles in the international references highlight that efficiency measurement should look for specific methods by considering the special features of public sector organizations. There is another widespread approach, too, according to which the achievement of public sector organizations can be reviewed and their performance measured by adapting principles and practical solutions of the business sector. Actually, it is the two sides of the same problem: on the one hand, the public sector organizations aim to distinguish themselves from the profit-oriented sector, on the other hand, they start to be similar to business entities from many aspects [Révész 2001]. The performance of these organizations can be examined by regarding both the efficiency of their activities and their fruitfulness.

Out of the several models examining the Hungarian non-profit sector, the following can be highlighted: methods of Non-profit Accountability Standards prepared by Farkas and Molnár in 2007 [Farkas, Molnár 2007]; the Index of Social Justice published by Hegyesi and Fekete in 2006 [Hegyesi, Fekete 2006]; as well as the research published by Kákai in 2008, in which the activities of the sector was introduced from a new aspect, which stressed the social participation going beyond the economic approaches [Kákai 2008].

Public sector organizations are interested to have concrete information that can be evaluated:

- $\quad$ in order to improve the efficiency and productivity of operation;

- in competitive financing environment, the funding organizations more and more frequently request information about the performance of the organization as a condition of grants and for monitoring reasons;

- performance information that can be well communicated is necessary for enforcing the reputation of organization and expanding its values;

- those concerned can be better stimulated by the outcome indicators and the objectives can be made more obvious [Pavluska 2006].

The operation of a public sector organization can be regarded successful, if its performance serves both the mission, the achievement of the objectives of founders and the maintenance of functionality. Therefore, adequate indicators should be constructed to express and evaluate performance. These indicators are suitable for expressing the categories of input, activity, output and efficiency. In the case of public sector organisations, these categories can be explained as follows [Pavluska 2006]:

- Inputs: resources rendered or used for the activities. Their quantifiable indicators are: the money utilized, means, equipment, infrastructure, employees, working hours spent, etc. The social and human capital resources, like motivation, attitude, value, skills, competencies and information, cannot be quantified. Input indicators include the information about costs of resources, regulations restricting operation and the requirements.

- Activities: express what happens in the organisation with the resources in order to enhance directly or indirectly the mission of the organization or the fulfilment of objectives. The activities can be expressed by techniques and dealings. 
- Outputs: direct outcomes of activities, which can be expressed - among other things - by the utilized labour volume, time of availability and capacity, number of clients and the persons reached, etc.

The performance, efficiency and achievements of the organization are considerably affected by the individual performances, and it is especially true in the educational institutions, where the „means of production” is the man, the teacher and the product is the student, the competencies developed in the students by the activities of the educational institution, the improvement of self-studying skills and - to a lesser extent - the substantive knowledge, provided to the students and questioned from them during their training courses.

The aim of the examination is to evaluate the measurement methods applied in a Hungarian university and a college, how these methods are able to measure performance objectively, what information they provide to the human resource managers and to the person who is measured. The research also aimed at examining the experiences and opinion about the importance and goals of performance measurement of employees working in higher education by a questionnaire survey.

\section{Material and methods}

Within the frames of the research the faculty and staff measuring systems of two Hungarian higher education institutions (one university and one college) are compared and the evaluation method and practice of an independent (de jure consultative, de facto decision-making) accreditation board concerning the measurement of professor habitude (life performance). The measuring systems were evaluated on the base of the official documents of the two institutions. The practice is regarded by the institutions as a reference in the evaluation of other teaching performances.

The questionnaire survey within the research was made with the employees of a Hungarian medium-size university about the measurement system applied at the institution, about their opinion connected with the objectivity of the system and the necessity of performance measurement.

The survey was performed with a questionnaire which was available on the intranet of the institution and could be completed electronically in 2010. All the employees holding email addresses received electronic invitations to complete the questionnaire and two reminders were also sent to them. The questionnaire was voluntary. The survey was carried out by the internal audit unit of the institution. Eight questions in the questionnaire were connected with demography, 13 asked the respondents about the awareness of performance measurement systems, their opinion concerning the suitability of these systems and 12 questions aimed the personal experiences of respondents in connection with performance measurement. The questions were typically multiple choice topics or the respondents should have evaluated on Likert scale. In some cases those responding could write short comments.

The number of employees at the date of research was almost three thousand, out of them 219 persons completed the questionnaire. 
Simple statistical methods were used in the evaluation of the questionnaire.

\section{Results}

\subsection{Assessment of the employee}

The assessment of the employee is made on a printed form in both examined institutions. The structure of assessment is the following: appraisal criteria, evaluated by the direct superior employer on a four-point scale (excellent -3 points, satisfactory -2 points, less satisfactory - 1 point, failed - zero point) and with a short written justification. The justification is mostly made with panel sentences.

The assessment of the civil servant is the ratio of scores aggregated from the individual measurement criteria compared to the maximum available scores: excellent (80100\%), suitable (60-79\%), less suitable (30-59\%) and unsuitable (below 30\%).

It is obvious that the applied evaluation model does not contain any concrete, quantifiable evaluation criteria (Table 1). The use of four-point scale, however, pretends that quantified, scale measurement was made but the evaluation, in fact, strongly depends on the evaluating person. It might result that the staff working in different units can get different assessment with the same performance or those working in the same unit can be different due to sympathy or antipathy, even in the case of the same performance.

So the method is inadequate for the actual, objective performance measurement, it does not give appropriate information about the competencies and their level of fulfilment either to the manager or the employee, thus it is not suitable for assisting the preparation of human resource development plans. The question is placed into a different perspective if it is considered that there were competing alternatives when the valid system was prepared. One of these alternatives intended to evaluate on the basis of a detailed index-system, while the other alternative aimed to set up a competency map in which the fulfilment of competencies relevant for a given activity sphere should have been evaluated on a five-point scale. The instructions for evaluation contained detailed description for the minimum and maximum values of each competency. 
TABLE 1.

Criteria system used for the measurement of civil servants

\begin{tabular}{|c|c|}
\hline \multicolumn{2}{|c|}{ Specific criteria of assessing civil servants } \\
\hline Other staff & Teachers, researchers \\
\hline - Professional skills required for the job & - Meeting the performance requirements \\
\hline - Professional, practical duties within the job & - Quality of performing teaching activities \\
\hline - Problem-solving ability connected with & - Level of scientific/art activities \\
\hline professional work & $\begin{array}{l}\text { - Participation in the community life of } \\
\text { the higher education institution }\end{array}$ \\
\hline \multicolumn{2}{|c|}{ General criteria of assessing civil servants } \\
\hline \multirow{3}{*}{\multicolumn{2}{|c|}{$\begin{array}{l}\text { - Responsibility and sense of vocation concerning the duties } \\
\text { - Accuracy, diligence and efforts connected with the duties } \\
\text { - Other criteria regulated by the executive orders }\end{array}$}} \\
\hline & \\
\hline & \\
\hline \multicolumn{2}{|c|}{ Assessment criteria connected with leading positions } \\
\hline of work at the oroanisational unit & \\
\hline
\end{tabular}

Source: own study

\subsection{Teaching staff assessment}

In addition to the above-outlined evaluation, two further methods are used for the measurement of teaching staff performance. In one of the methods, the student evaluate the performance of the teacher, while the other calculates - as a performance indicator - the time spent on teaching, research, publication activity, participation in public activities at the institution and in talent management (on the basis of self-declaration). The latter, if properly documented and controlled, can be the basis of the evaluation of a period and a life performance. At the same time, it could be more efficient if appropriate feedback was made (which is currently missing) and it would help the determination (positioning) of the own situation by the person evaluated. It would provide adequate amount of information to the management as well as to the evaluated person and would help to prepare personalized development plans.

\subsection{Evaluating the suitability to requisites of professorship}

This measurement system has been prepared by the human resource management in order to evaluate life performance based on key performance indicators (KPIs). The measurement system was set up by an accreditation committee which works independently from the institutions, with several alternatives considering the specific features of scientific fields. The indicators cover the scientific, teaching and school-based activities, national and international professional-scientific recognition and activity. Scores are rendered to the evaluation of each category. The scores are limited by the groups of 
evaluation indices, setting a minimum value to meet and a maximum value which can be given.

The evaluation is up-to-date, it is really suitable for measuring the performances. Those concerned, however, should face that in many cases, in spite of the realized performance, which meets the requirements, the (subjective) qualification is not based with facts. It creates uncertainty for those who are evaluated because they would not know what are the prerequisites they should meet and what are the areas they should improve.

\subsection{Opinion of employees about the performance measurement}

The outcome of questionnaire survey is very far-reaching. Only a few results are highlighted from the many. The research has made it obvious that the practice experienced by the employees determines their knowledge concerning the performance measuring methods and the complex evaluation systems are not widely known. At the same time, the teaching-research staff declared that they knew a few methods. The opinion about the suitability of possible evaluation methods included in the questionnaire - except for operational staff - is not significantly different in case of the individual measurement methods. On the other hand, the evaluation based on the subjective judgement of the management received significantly lower average value in all the responding groups. It leads to the conclusion that the employees regard subjective or presumably subjective evaluation methods less adequate for measuring the performance of employees (Table 2).

Interesting outcomes were received from the question, where the performance measurement is applied. The fact itself, that the respondents were sceptical about the application of evaluation methods (because they could tick more answers at a time), they did not regard the use of methods determinant in any of the possible field of use (except for the bonus in case of operational staff). The teachers and researchers see the role of performance measurement primarily in connection with promotion and rewarding. The low value of awards (moral recognition) is very surprising. It has not very important role in the determination of wages, partly due to the centrally fixed table of wages and partly due to the limited budget sources, as it is well-known for everybody. (Table 3). 


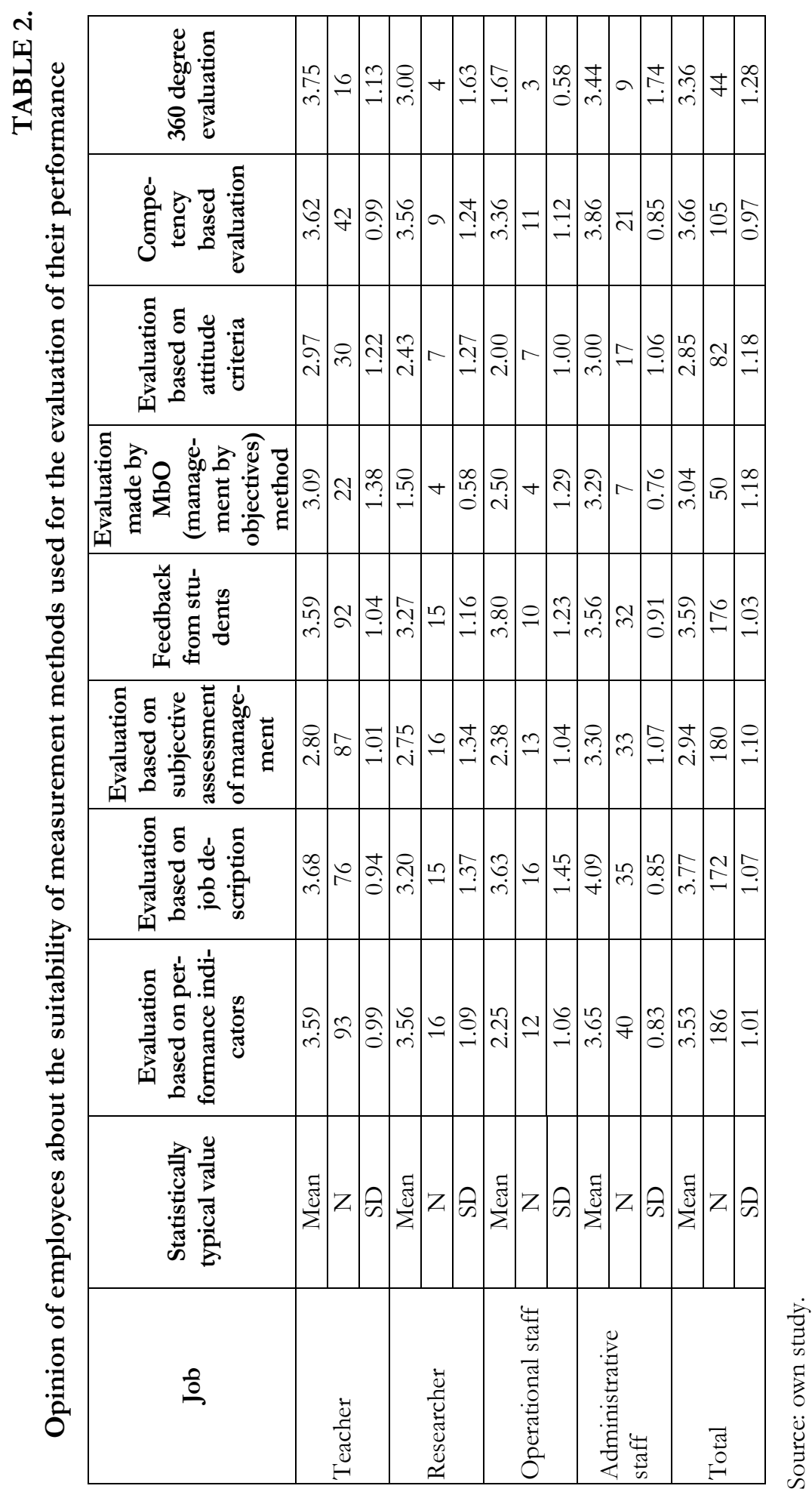


TABLE 3.

Opinion of employees about the areas where performance measurement is used

\begin{tabular}{|l|c|r|r|r|r|}
\hline \multirow{2}{*}{ Job } & \multirow{2}{*}{$\begin{array}{c}\text { Number of } \\
\text { respondents }\end{array}$} & \multicolumn{4}{|c|}{ Field of use } \\
\cline { 3 - 6 } & Promotion & Wages & \multicolumn{1}{c|}{ Award } & \multicolumn{1}{c|}{ Bonus } \\
\cline { 3 - 6 } & (capita) & \multicolumn{4}{|c|}{ in \% of respondents } \\
\hline Teacher & 99 & 34.3 & 14.1 & 23.2 & 29.3 \\
\hline Researcher & 16 & 25.0 & 12.5 & 18.8 & 12.5 \\
\hline Operational staff & 20 & 10.0 & 10.0 & 10.0 & 20.0 \\
\hline Administrative staff & 50 & 22.0 & 32.0 & 26.0 & 52.0 \\
\hline Total & 219 & 28.3 & 18.7 & 23.3 & 35.2 \\
\hline
\end{tabular}

Source: own study.

A small number of executive staff also replied the questions. Due to the size of the sample we have not made any detailed statistical analysis, but it was our informative statement that $66 \%$ of the responding executives used the evaluations we made in their decisions concerning the promotion of employees, $69 \%$ used in proposals for awards, $46 \%$ in decisions concerning bonus payment and only $31 \%$ in decisions concerning salaries.

\section{Conclusions}

Higher education institutions operate on the border of non-profit and the business sector. Although the state higher education institutions are financed from state budget, they are also connected to the business sector through a lot of channels and they also perform business activities - both in the field of education and research. Thus, the performance measurement made in higher education should consider, on the one hand, the special features of public sector organizations, including higher education, and, on the other hand, the business efficiency and profitability can also be explained by considering the limiting conditions.

The problems of performance measurement often result that the executive heads choose the simpler solutions and instead of preparing and implementing real and objective measuring systems, they rather use assessment (performance measuring) systems which are based on less facts and data and reflect the subjective opinion of the evaluating person.

More systems are applied at a time, out of which many are well-parametered according to the special features of the field to measure, but these are not or only partly integrated, and they do not have any roles in qualification. Feedback is often missing, too, which is an important function of performance measurement. Thus, it does not support the planning of personal development of the employee. 
In the case of well-parametered measuring systems, the fixed reference levels and their changes can be problematic because they may result that the evaluated persons cannot predict their own positioning and cannot realize their own career plans.

The employees usually do not have any adequate information concerning the performance measurement methods and their opinion about the suitability of these methods is usually not too good. It should be stressed, however, that they reject the subjective evaluation methods because these depend on their personal relation with the management more than on their actual performance. The research also confirms that the employees require predictable measurement based on key performance indicators (KPIs) with the help of which the corporation heads can pursue efficient human resource management with personalized development plan for each employee. By the feedback and the identification of place among the other participants of the organization, the measurement system will bring the employee in real competitive and decision situation. And ultimately, it will positively affect the organizational culture, too [Ridder et al. 2011].

\section{Bibliography}

Adams J. S. 1965 Inequity in Social Exchange, "Advances in Experimental Social Psychology", 62. pp. 335-343.

Akingbola K. 2012 A Model of Strategic Nonprofit Human Resource Management, International Society for Third-Sector Research and The John's Hopkins University, Voluntas, 27 p.

Báger G., Jánossy D., Kovács R., Pulay Gy. (ed.), Tököli L., Vigvári A. 2009 Az állam célszerú gazdasági szerepvállalása a XXI. század elejének, globális gazdaságában, Tanulmány, Állami Számvevőszék Kutatóintézete. Budapest. 95 p.

Bartal A. M. 2005 Nonprofit elméletek, modellek, trendek, Századvég Könyvkiadó, Budapest, 316.p.

Bourne M., Neely A., Mills J., Platts K. 2003 Implementing Performance Measurement Systems: a literature review, "International Journal of Business Performance Management" 5 (1). pp. 1-24.

Breakwell G. M., Tytherleigh M. Y. 2010 University Leaders and University Performance in the United Kingdom: Is it 'Who' Leads, or 'Where' They Lead that Matters Most?, "Higher Education", 2010 (60). pp. 491-506.

Caplice C., Sheffi Y. 1995 A Review and Evaluation of Logistics Performance Measurement Systems, "International Journal of Logistics Management", 6 (1). pp.61-74.

Doran G. T. 1981 There's a S.M.A.R.T. Way to Write Management's Goals and Objectives, "Management Review", 70 (11) (AMA FORUM). pp. 35-36.

Farkas F., Molnár M. 2007 A magyar nonprofit szeektor szervezeteinek elszámoltathatósááat értékel"o standardok és módszertan, "Statisztikai Szemle" 85 (9). pp. 804-820.

Hegyesi G., Fekete O. 2006 Kisérlet a nonprofit szervezetek felmérésére a Társadalmi Igazságosság Index segitségével, "Civil Szemle", 3 (1). pp. 5-33.

Hoecht A. 2006 Quality Assurance in UK Higher Education: Issues of Trust, Control, Professional Autonomy and Accountability, "Higher Education", 2006 (51). pp. 541-563. 
Kákai L. 2008 A szervezetek müködését befolyásoló problémák, "Civil Szemle” 5 (3). pp. 22-36.

Kelvin W. T. 1889 From Lecture to the Institution of Civil Engineers, London (3 May 1883). 'Electrical Units of Measurement', Popular Lectures and Addresses (1889). Vol. 1, 80-81. In Online: http://todayinsci.com/K/Kelvin_Lord/KelvinLord-Quotations.htm. Download: 23.05.2012.

Kotosz B. 2012 Measuring Sustainable Development at Aacro Level, [in:] Zentková I., Pokrivčák J., Hanová M., Tóth M., Pogranová Z. (eds.), Global Commodity Markets: New Challenges and the Role of Policy: International Scientific Days 2012, Nitra, Szlovákia, 2012.05.16-2012.05.18, Nitra: Slovak Agricultural University in Nitra, 2012. pp. 707712.

Lannert J. 2004 Hatékonyság, eredményesség és méltányosság, Tanulmány, Új Pedagógiai Szemle. 2004. december 15. p.

Marrewijk M. van, Timmers J. 2003, Human Capital Management: New Possibilities in People Management, "Journal of Business Ethics", 2003 (44). pp. 171-184.

McGregor D. 1960 The Human Side of Enterprise, McGrawHill, New York, 423 p.

Meadows D. 1998 Indicators and Information Systems for Sustainable Development. A Report to the Balaton Group, The Sustainability Institute, Hartland Four Corners VT. 78 p.

Meyer P. J. 2003 What Would You Do if You Knew You Couldn't Fail? Creating S.M.A.R.T. Goals. Attitude Is Everything: If You Want to Succeed Above and Beyond, Meyer Resource Group, Incorporated. $26 \mathrm{p}$.

Neely A. D., Mills J. F., Gregory M. J., Platts K. W. 1995 Performance Measurement System Design - A Literature Review and Research Agenda, "International Journal of Operations and Production Management", 15 (4). pp. 80-116.

Neely A., Gregory M., Platts K. 1995 Performance Measurement System Design - A Literature Review a Research Agenda, "International Journal of Operations Production Management", 15 (4). pp. 80-116.

Pavluska V. 2006 Teljesitménymérés és teljesitményértékelés a nonprofit szervezetekben, 1. pp. 2436.

Révész É. 2001 A teljesitmény értelmezése és értékelése nonprofit szervezetekben, Kézirat, Budapesti Corvinus Egyetem.

Ridder H.-G., Piening E. P., Baluch M. A. 2011 The Third Way Reconfigured: How and Why Nonprofit Organizations are Shifting Their Human Resource Management, International Society for Third-Sector Research and The John's Hopkins University, Voluntas, 31 p.

Wimmer Á., Mandják T., Esse B. 2010 Perception and Practice of the Supplier Relationship Management, [in:] The 26th IMP Conference: Business Networks Globality, Regionality, Locality, Budapest. 2010.09.02-2010.09.04. Corvinus University of Budapest. pp. 1-12.

Zhang M., Li H., Wei J. 2008 Examining the Relationship between Organizational Culture and Performance, "Frontiers of Business Research in China", 2 (2). pp. 256-276. 